\title{
BARBARZYŃCY I KOCZOWNICY. MARZENIA I FOBIE
}

\author{
Lajos PÁlfalvi ${ }^{1}$ \\ (Katolicki Uniwersytet im. Pétera Pázmánya, Piliscsaba)
}

\begin{abstract}
Słowa kluczowe: auto- i heteroobrazy koczowników, piekło Słowian, barbarzyńska Europa, archaiczna cywilizacja rolnicza, węgierska idea narodowa Keywords: auto- and hetero-images of the nomads, hell of the Slavs, barbarian Europe, ancient agriculture, the Hungarian idea of nation
\end{abstract}

\begin{abstract}
Abstrakt: Lajos Pálfalvi, BARBARZYŃCY I KOCZOWNICY. MARZENIA I FOBIE. „PORÓWNANIA" 2 (21), 2017, S. 55-64. ISSN 1733-165X. W esejach Jerzego Stempowskiego i Stanisława Vincenza znajdujemy opisy reliktów prastarej kultury rolniczej zagrożonej przez koczowników. W mitologii słowiańskiej są oni utożsamiani z takimi „katami Słowian” jak Árpád. W tożsamości europejskiej mieszczą się tradycja klasyczna i cywilizacja barbarzyńska. Ta ostatnia została nobilitowana w syntezie Karola Modzelewskiego pt. Barbarzyńska Europa, natomiast koczownictwo nadal pozostaje obcym elementem. W historiografii węgierskiej pierwszej połowy $X X$ wieku powstała zaś pogłębiona refleksja na temat koczownictwa. Wybitny historyk, Tibor Joó (19011945), w monografii pt. Nacjonalizm wegierski (Magyar nacionalizmus, 1941) rekonstruował i interpretował na nowo zapomniane tradycje węgierskie.
\end{abstract}

\begin{abstract}
Lajos Pálfalvi, BARBARIANS AND NOMADS. FANTASIES AND PHOBIAS.“PORÓWNANIA" 2 (21), 2017, P. 55-64. ISSN 1733-165X. The essays of Jerzy Stempowski and Stanislaw Vincenz describe the reminiscences of the age-old agricultural cultures which have always been threatened by the nomadic people. In the Slavic mythology terms such as "the executioners of the Slavs" have been identified with figures like Árpád. The ancient tradition and the barbaric civilization are part of the European tradition. The latter has been ennobled by Karol Modzelewski in his synthesis: Barbarian Europe, but the nomads still remain an alien element. The Hungarian historiography of the first half of the 20th century produced a deep reflection on nomadism. The eminent historian, Tibor Joó (1901-1945), reconstructed and reinterpreted the forgotten Hungarian traditions in his monograph: Hungarian Nationalism (1941).
\end{abstract}

Porównując węgierski epizod życia Stanisława Vincenza i Jerzego Stempowskiego, od razu możemy zauważyć, że Vincenz świetnie się zintegrował z mniejszy-

1 E-mail: idegen-toll@t-online.hu 
mi i większymi wspólnotami społeczeństwa węgierskiego (nie tylko w środowisku uchodźstwa polskiego), natomiast Stempowski wybrał odosobnienie, niechętnie opuścił północno-zachodnią strefę przygraniczną. Nie chciał zostać długo na Węgrzech, już wiosną roku 1940 opuścił kraj. Vincenz poznał kulturę węgierską (elitarną i ludową), nauczył się węgierskiego, doskonale się orientował. Chociaż był miłośnikiem gór, mógł z entuzjamem pisać o krajobrazach węgierskich, nie tylko o Zakolu Dunaju (Brama do Węgier), ale także o południowej części Niziny Węgierskiej (Pole Bobrowe). Nie wpadł w depresję, widząc Cisę w Segedynie - znaną jako bystrą górską rzekę z Karpat - zmienioną w mulisty Nil.

Natomiast Stempowski czuł się wyobcowany na Węgrzech, bo wybitny poliglota, który był w stanie odróżnić ze słuchu wszystkie dialekty słowiańskie od Petersburga do Bratysławy, był bezradny wobec języka i kultury, która była dla niego nie tylko hermetyczna, ale w pewnym sensie wroga. Chociaż najważniejsze eseje Stempowskiego wyszły w przekładzie węgierskim już w roku 1999 (Stempowski 1999), więc recepcja w tym języku nie jest najgorsza, półroczny pobyt autora na Węgrzech nie mógł być wykorzystany do jego popularyzacji, bo właściwie nie doszło do spotkania z miejscową kulturą.

Po wydaniu korespondencji Jerzego Stempowskiego i Jerzego Giedroycia stało się jasne, że eseista patrzył bardzo krytycznie nawet na powstanie węgierskie w 1956 roku (w polskiej emigracji tego okresu nie ma przykładu takiej negatywnej oceny). Buntownik węgierski pojawia się w liście Stempowskiego jako groźny, nieodpowiedzialny element, który szkodzi sobie i innym. Nie zna alfabetu polityki, bo nigdy nie miał sojuszników zachodnich. Traktuje poważnie bezpodstawne obietnice, swoim buntem zmusza Moskwę do interwencji. To może mieć fatalny wpływ na ewolucję komunizmu: bolszewicy prowokowani przez Węgrów mogą deportować całe narody z Europy Środkowej na Syberię (zob. Giedroyc, Stempowski 413).

Te fobie muszą mieć jakąś głębszą przyczynę. Stempowski miał bardzo długą pamięć historyczną. Chwalił archaiczną kulturę rolniczą, szukał śladów tej prastarej cywilizacji na zachodzie i wschodzie Europy. Jego mistrzem był francuski profesor, Gaston Roupnel. Zdaniem wybitnego historyka

w początkach okresu historycznego Europa zachodnia posiadała już wcale gęste zaludnienie i cywilizację rolniczą liczącą od dwudziestu do pięćdziesięciu tysięcy lat. Część istniejących dziś pól, pastwisk, dróg, miedz i skrajów lasu pochodzi z tego okresu i nie uległa większym zmianom w czasach historycznych (Stempowski 1993: 81).

W opisach Ukrainy często narzeka na brak ciągłości kultury, bo po pięknych okresach ewolucji groźni i źli koczownicy napadali na spokojnych rolników, którym burzyli cywilizację. Moim zdaniem w jego wizji koczownicy są bohaterami negatywnymi historii. Tolerancja eseisty nie jest bezgraniczna, nomadyzm nie mieści się już w paradygmacie Europy. 
Badacze eseistyki Stempowskiego już zwrócili uwagę na to, że understatement jest jednym $z$ jego ulubionych chwytów retorycznych, dzięki niemu jest w stanie sformułować druzgocącą krytykę w sposób bardzo umiarkowany. Cytuje angielskiego historyka, który podał proste wyjaśnienie na to, dlaczego Dżengis-Chan, "szef barbarzyńskich nomadów”, masakrował ludność ujarzmionych krajów: „nie znał wartości pracy i nie wiedział, co począć z takim mnóstwem ludzi” (Stempowski 2001: 118) ${ }^{2}$. Kultura węgierska nie pasuje więc do jego kanonu, naród węgierski jest obcym elementem w żywiole słowiańskim. Węgrzy nie tylko ze względu na pochodzenie są wykluczeni z klubu czcigodnych rolników (chociaż już od dawna nie wędrują). Stempowski musiał znać słowiańską romantyczną mitologię koczowników, na przykład Slávy dcera Jána Kollára. Árpád występuje w tym utworze razem z Batu-chanem, bo on również należy do katów Słowian. Kraj Węgrów nadal był piekłem Słowian - być może Stempowski też czuł się jak w piekle w czasie pobytu na Węgrzech.

Najbardziej archaiczna warstwa cywilizacji europejskiej została niedawno w bardzo ciekawy sposób przeinterpetowana przez wybitnego historyka, Karola Modzelewskiego. W wielkiej syntezie pod tytułem Barbarzyńska Europa opisuje cywilizację plemion germańskich, słowiańskich, bałtyjskich i ugrofińskich osiedlonych poza limesem Imperium Rzymskiego. Termin barbarzyńca dla Modzelewskiego nie wiąże się z dzikością, ale właściwie nie ma nic nowego w takim pozytywnym przewartościowaniu tej kategorii. Już Rzymianie widzieli w barbarzyńcach "szlachetnych dzikusów", szukali w nich swojej lepszej jaźni. Tacyt na przykład, piętnując "rozwiązłość swoich własnych współobywateli”, postawił za wzór barbarzyńców: „Przetykany pochwałami opis surowości obyczajowej Germanów służył do prawienia morałów dekadenckiemu Rzymowi. Stereotyp «szlachetnego barbarzyńcy» miał stawiać przed oczy cywilizowanemu światu wzór zapomnianych cnót" (Modzelewski 41). W średniowieczu też powstały podobne konstrukcje: „barbarzyńcy, a przecież pod wieloma względami zacniejsi od Rzymian; poganie, a przecież w niejednym lepsi od chrześcijan" (Modzelewski 44).

Epoka przedchrześcijańska, przedpaństwowa budziła zainteresowanie w XIX wieku jako pierwszy, mało znany rozdział historii narodowej. Badacze szukali w przeszłości odpowiedników współczesnych im konfliktów etnicznych. Modzelewski powołuje się na programowy esej Reinharda Wenskusa, który

podkreślił, że obszary charakteryzujące się podobieństwem struktur społeczno-ustrojowych nie pokrywają się z obszarami wspólnot językowych. [...] Zwracał uwagę na kulturową odrębność stepowych ludów koczowniczych oraz plemion zamieszkujących puszczańskie terytoria na północnym wschodzie subkontynentu, traktował jednak plemiona celtyckie, germańskie, słowiańskie i bałtyjskie jako jeden krąg kulturowy, w ob-

2 Piszę o tym szerzej w: Pálfalvi 2015. 
rębie którego tradycyjne społeczeństwa zorganizowane były na zbliżonych zasadach (Modzelewski 12).

Słowiańsko-germańską rywalizację zastępuje perspektywa jedności kulturowej. Zdaniem Andrzeja Mencwela synteza Modzelewskiego rozszerzała horyzonty europejskości. Udowodnił on, że ta cywilizacja ma nie dwa, a trzy źródła: obok tradycji grecko-rzymskiej i judeochrześcijańskiej ważna jest „tradycja pierwotnych mieszkańców tej części Europy”. Tradycję autochtoniczną „tworzyli Germanie, Bałtowie, Słowianie" przed przyjęciem chrześcijaństwa (Mencwel 109).

Najważniejsze zasady organizacji tego społeczeństwa to pokrewieństwo i sąsiedztwo. Rodzinna, rodowa i plemienna wspólnota zapewnia swoim członkom „nie tylko przetrwanie, ale także bezpieczeństwo, współdziałanie i opiekę" (Mencwel 116-117). System pokrewieństwa jest bardzo skomplikowany, terminologia polska zawiera „około czterdziestu określeń". Taka wspólnota decyduje nie tylko o podziale pracy i zasobów. Modzelewski w podrozdziale pod tytułem Wspólna wina, wspólny honor, wspólna przysięga opisuje kolektywistyczny wymiar norm moralnych. Na przykład:

zabójstwo traktowano jako cios zadany rodowi ofiary prez ród zabójcy. Pokrzywdzonymi byli nie tylko domownicy i bliska rodzina, ale także dalsi kuzyni aż do piątego, szóstego lub siódmego stopnia pokrewieństwa. Wszyscy oni ponieśli stratę i wszystkim wyrządzono zniewagę, jeśli więc strona przeciwna nie złożyła okupu, to wspólny honor rodu nakazywał wyrównać stratę przez odwetowy cios i zmyć zniewagę krwią wroga. Okup składał cały ród zabójcy (Modzelewski 155).

Można zrywać z rodem i przejść do innego, ale nie można żyć poza wspólnotą. Współplemieńcy trzymają jednostkę pod kontrolą, wymagają posłuszeństwa, za naruszenie najważniejszych norm karzą winnego wykluczeniem z tej wspólnoty - właściwie z cywilizacji ludzkiej. Buntownika nazywają wilkiem, rujnują jego domostwo.

Organizacja przestrzenna jest nie mniej zróżnicowana: „terytoria barbarzyńskich plemion składały się z wielu ogniw lokalnych niczym plaster miodu z komórek" (Modzelewski 287). Mniejsze i większe wspólnoty tworzą skomplikowaną hierarchię: opole, wspólnota sąsiedzka jest większa od krewniaczej, natomiast jest składnikiem wspólnoty plemiennej. Najwyższym stopniem organizacji społeczeństwa w epoce przedpaństwowej jest związek plemion. Każda jednostka doskonale wiedziała, gdzie jest jej miejsce w tym systemie rodowo-terytorialnym, wiedziała, jakie ma obowiązki i czym płaci za nieposłuszeństwo.

Stempowski - komentując sagę huculską Vincenza - wyobraża stan przedhistoryczny starej kultury rolniczej jako najwyższy stopień harmonii i równowagi. Tu jeszcze nie ma kumulacji władzy i dóbr materialnych, potomstwo nie dziedziczy od wczesniejszych pokoleń piramid i fortyfikacji, bo żyje według rytmu przyrody. Ba- 
dania naukowe Modzelewskiego właściwie nie zaprzeczają intuicji Stempowskiego: „Nie ma wielkiej własności i nie ma odrębnych stanów - różnice społeczne są «różnicami stopnia»[...]. Człowiek więc żyje tutaj wśród biskich i prawie równych, spontanicznie dających sobie wzajemnie pomoc i oparcie" (Mencwel 118).

Według interpretacji Mencwela ten trzeci filar cywilizacji europejskiej jest nie tylko niedocenioną dotychczas tradycją, w tym regionie „bije ważne źródło nowoczesnej Europy". Poza tym koncepcja Modzelewskiego daje mocniejsze podstawy takim tekstom kluczowym jak Rodzinna Europa Czesława Miłosza, Trzy Europy Jenő Szúcsa i Młodsza Europa Jerzego Kłoczowskiego (zob. Mencwel 112). Synteza Modzelewskiego określa o wiele głębiej swoistość Europy Środkowo-Wschodniej, rozszerza kanon europejskości, ma wielki potencjał emancypacyjny - ale nie dotyczy tradycji koczowników. Z węgierskiego punktu widzenia może nawet wzmacniać kompleks obcości, bo możemy ją czytać w ten sposób: nobilitowano barbarzyńców, na scenie pozostał jedyny czarny charakter. Koczownika oddziela przepaść cywilizacyjna nie tylko od Rzymian i Greków, ale także od uduchowionych rolników.

Gdybym miał ująć te tradycje w XXI-wiecznych pojęciach, przeciwstawiłbym sobie te dziedzictwa w następujący sposób: osiedlonemu trybowi życia odpowiada działanie według reguł firm rodzinnych, natomiast koczownicy zajmują się zarządzaniem projektami w szerszych ramach. Organizują intensywną współpracę różnych, większych i mniejszych grup. Zasady pokrewieństwa i sąsiedztwa nie odgrywają kluczowej roli. W tej chwili nie interesują mnie takie adaptacje tradycji koczowników jak ponowoczesny nomadyzm Viléma Flussera, cyfrowy nomadyzm i inne. Nie chcę komentować tego, skądinąd ciekawego zjawiska, że w ostatnich dwóch dekadach nomadyzm stał się spektakularnym elementem popkultury węgierskiej. Puszta, stado koni i gulasz w kotle od dawna są stałymi elementami mitologii węgierskiej, natomiast ostatnio pojawiły się takie nowe rytuały jak kurultaj, swoisty festyn i wiec plemienny na Nizinie Węgierskiej, na który są zapraszane delegacje z Azji Środkowej i nawet z Mongolii. W ostatnich dziesięciu latach niektórzy badacze głoszą, że plemię Madjar, żyjące w Kazachstanie, w regionie Torgaj od trzystu-czterystu lat jest spokrewnione z Węgrami. Produkowanie różnych gadżetów pseudonomadyzmu stało się osobną gałęzią przemysłu na Węgrzech. Krzysztof Varga także zauważył już to zjawisko i opisał je w swojej książce pod tytułem Czardasz $z$ mangalica.

Chciałbym przedstawić koncepcję wybitnego węgierskiego historyka idei, o którym nie mówiono w czasie "hegemonii marksizmu”, to znaczy do roku 1990. Po tym okresie znów wydano jego utwory, ale nie stał się on modny, właściwie nadal jest autorem znanym tylko w gronie specjalistów. Jego idee nie mają nic wspólnego ani z alternatywnymi teoriami o pochodzeniu języka i narodu węgierskiego ${ }^{3}$, ani z modą na popkulturowy pseudonomadyzm. Monografię Tibora Joó (1901-1945)

3 Piszę o nich w artykule: Pálfalvi 2011. 
pod tytułem Nacjonalizm wegierski możemy postawić obok Barbarzyńskiej Europy Modzelewskiego, bo uzupełnia obraz, chociaż nie w sensie przedstawiania tradycji koczowników jako czwartego filaru cywilizacji europejskiej. Raczej wyjaśnia ona sens koczownictwa, które w wyobraźni dziedziców prastarej cywilizacji rolniczej kojarzy się z chaosem, gwałtem, zburzeniem kultury. Joó opisuje cywilizację pozaeuropejską, ale nobilituje koczowników tak samo, jak Modzelewski barbarzyńców. Poza tym Joó również przedstawia większą całość kulturową, a nie szuka miejsca uprzywilejowanego dla własnego narodu w rywalizacji etnosów i plemion. On też bada fazę przedpaństwową, przedchrześcijańską. Szczytem rozwoju społeczeństwa koczowniczego także był związek plemion, następnie przeszło do epoki historii pisanej. Po przyjęciu chrześcijaństwa omawiane społeczeństwo niewiele zachowało ze swojego dawnego dziedzictwa kulturowego, ale mimo wszystko pewne głębsze struktury są nadal zauważalne dla badacza.

Joó doktoryzował się z filozofii, zajmował się przede wszystkim węgierską ideą narodu i filozofią historii. Jako publicysta (a w pewnym sensie także jako naukowiec) wystąpił przeciwko nazizmowi i węgierskim proniemieckim grupom. Pracował w różnych bibliotekach, jego kariera uniwersytecka zaczęła się dopiero w roku 1939. Został zraniony w czasie szturmowania Budapesztu, zmarł pod koniec wojny. Badał ideę narodu poza kontekstem biologizmu, darwinizmu i rasizmu.

Najważniejszym doświadczeniem historycznym Joó (urodzonego $\mathrm{w}$ stolicy Siedmiogrodu, w Kolożwarze) była katastrofa historycznych Węgier. W jego interpretacji tysiącletnie królestwo stało się ofiarą nacjonalizmów. Epoka nomadyzmu plemion węgierskich pojawia się jako antyteza nowoczesnych - dla Węgrów zabójczych - zachodnich koncepcji narodu. Koczownictwo jest zaprzeczeniem zasady etnicznej, z tej tradycji wynika rozdzielenie państwowości i narodowości. W opisie Joó najstarszym dziedzictwem Zachodu jest partykularyzm plemienny, wspólnota budowana na podstawie biologicznej4.

Tryb życia konnych koczowników był zupełnie inny. Byli oni traktowani do niedawna jako dzicy barbarzyńcy, którzy masakrują i grabią cywilizowane narody. W historii pisanej nie mają żadnej roli poza destrukcyjną. Węgrzy po osiedleniu w Basenie Karpackim sami cierpieli z powodu inwazji mongolskiej, więc oni także ocenili koczowników z perspektywy europejskiej, wstydzili się tych tradycji, próbowali udowodnić, że również byli rolnikami. Joó, kreśląc pozytywny obraz koczownictwa, pokazał, że Węgrzy nie muszą odrzucać swoich tradycji czy fałszować swojej przeszłości poprzez stosowanie się do wymagań otoczenia. Stepowi koczownicy pośredniczyli między plemionami mieszkającymi daleko od siebie, zjednoczyli te szczepy w imperia. Przyczynili się do wędrówki ludów, współtworząc dzisiejszą Europę, przekształcając Azję. Nie można traktować trybu życia, kultury i organi-

$4 \mathrm{~W}$ wielu legendach pojawia się motyw porwania dziewic, natomiast w wersjach mongolskich chętniej porywa się kobiety w ciąży, żeby nie musiano tak długo czekać na potomstwo. 
zacji społecznej koczowników jako niższego poziomu kultury czy antycywilizacji. Koczownicy tworzą takie wspólnoty, które można rozszerzać do nieskończoności, bo nie ma w nich ani separacji, ani wyłączności.

Osiadły tryb życia implikuje rozwój od rodziny przez ród, plemię, lud, naród do państwa. Koczownicy wybierają partnerów do kontaktów nie według pokrewieństwa. Pasterze zagospodarowują duże tereny, współpracując z obcymi i różnymi fachowcami (rzemieślnikami, rolnikami, traperami). Majątek nie może być podzielony z przyczyn ekonomicznych, więc powstaje większa rodzina. Szef rodu ma być zdolnym organizatorem, a jeżeli ma spektakularne sukcesy, obcy też chcą działać pod jego patronatem. Po pewnych rytuałach można ich przyjąć do wspólnoty, która jest raczej całością symboliczną, sztuczną, zorganizowaną na podstawie jakiejś idei. Plemię koczowników jest związkiem rodów, organizacją polityczną. Członkowie plemienia mają krewnych $\mathrm{w}$ różnych rodach i szczepach.

Związek plemion jednoczy wiele etnosów, czasami nawet członkowie tej samej grupy mówią różnymi językami. Według opisu Joó w plemieniu wodza Węgrów wojownicy byli Turkami, a rolnicy Ugrofinami. Pasterstwo koczownicze wymaga pilnowania stad, trzeba bronić pastwisk i zdobywać nowe. Pasterz również ma być bojownikiem, a potem powoli zmieni się jego rola w podziale pracy. Żyje w symbiozie z ludami służebnymi, jest przekonany o tym, że człowiek wolny jest stworzony do walki. Wykonywana praca staje się dla niego niegodna, stada pilnują już słudzy.

Współpraca pasterzy-wojowników z innymi fachowcami już we wczesnej fazie rozwoju tworzy skomplikowane życie społeczne, taką organizację polityczną, w której współżyją różne etnosy mówiące wieloma językami, nieoddzielone od siebie granicami naturalnymi. Taka cywilizacja powstała na Wielkim Stepie, w Turanie czy na ziemi północnych barbarzyńców (według terminologii chińskiej). Warstwa panująca nie asymiluje szczepów podporządkowanych, nie narzuca im swojego języka, lecz próbuje stworzyć z nich imperium. Panowanie warstwy kierowniczej jest znośne, tolerancyjne, nie ma nic wspólnego z bezwzględnym despotyzmem, natomiast podbój jest okrutny, bo niewielka grupa wojowników ma zmuszać do posłuszeństwa całe plemiona. Gdy zawrą pokój i ustalą nowy porządek, nie niszczą miasta i osiedla, ale próbują zagospodarować nowe tereny. Czasami wojownicy zasymilują się do narodu podbitego jako warstwa panująca (tak Chińczycy Han zasymilowali Mandżurów).

Z powyższego wynika, że prastare kultury wysokie były współtworzone przez koczowników, którzy zjednoczyli i zorganizowali mniejsze grupy rolników. Zdaniem niektórych archeologów także europejska prakultura zawdzięcza swój rozwój w końcu epoki brązu koczownikom konnym, bo dzięki ich obecności pojawiły się w gospodarstwie koń i żelazo. Koczownicy potrafili współistnieć z miastami, traktowali je jako źródło podatku i miejsce targu. Gwarantowali im bezpieczeństwo, sami zakładali miasta. Nie zmieniali trybu życia, obyczajów i wiary ludów podbitych (tak został przedstawiony dwór Attyli w Pieśni o Nibelungach). Priskos 
Panites opisuje Hunów i Scytów jako narody mieszane, wydaje mu się, że nawet warstwa panująca nie ma języka ojczystego. Nawet imię Attyla pochodzi z języka gockiego, znaczy 'ojczulek'. Najwyższa warstwa nie jest kastą zamkniętą, najlepsi mogą być przyjęci.

Mao-Tun, władca Hunów, założyciel azjatyckiego imperium pisze w liście do cesarza Chin: „ujarzmiłem 26 imperiów, wszystkie ludy, które naprężają łuki, stały się Hunami, zjednoczyli się w jednej rodzinie" (cyt. za Joó 75). Przedstawia imperium jako rozszerzoną rodzinę, budowaną nie na zasadzie pokrewieństwa. „Naprężenie łuków" jest symbolem trybu walki koczowników. Między plemionami a imperium nie ma instancji pośredniej. Jeżeli szczęście odstępuje od władcy, traci on swój charyzmat, a imperium się rozpada. Plemiona żyją dalej w innych konfiguracjach, pod inną nazwą. Mit żyje w rodzinach i plemionach, między innymi w dynastii Ârpádów.

Struktura plemienia jest podobna do takich imperiów: nie ma tak zróżnicowanej hierarchii, jaką stworzyli europejscy barbarzyńcy. Tylko pozycja przywódcy jest stabilna (póki zachowuje swój charyzmat), na niższych poziomach panuje raczej chaos i anarchia. Te cywilizacje rzeczywiście są różne, ale to nie znaczy, że jedna z nich jest twórcza, a druga destrukcyjna. Koczownicy też tęsknią za długotrwałą, spokojną pracą twórczą (chociaż po pewnym czasie męczy ich klaustrofobia), a rolnicy czasami też chcieliby zacząć wszystko od nowa gdzieś daleko. Vincenz zrozumiał to, wydaje się natomiast, że nie rozumiał tego Stempowski.

W 1988 roku zorganizowano w Budapeszcie międzynarodową konferencję na temat twórczości Vincenza. Irena Vincenz wysłała telegram uczestnikom konferencji, w którym zacytowała wiersz pod tytułem Chłopskie lato klasyka poezji węgerskiej, Endre Adyego: „Szczęśliwy jest ten, kto zawsze może zaczynać od nowa”.

\section{BIBLIOGRAFIA}

Giedroyc Jerzy, Stempowski Jerzy. Listy 1946-1969. Część pierwsza. Wybrał, wstępem i przypisami opatrzył A.S. Kowalczyk. Warszawa: Czytelnik, 1998.

Joó, Tibor. Magyar nacionalizmus. Budapest: Athenaeum, 1941.

Mencwel, Andrzej. Wyobraźnia antropologiczna. Próby i studia. Warszawa: Wydawnictwa Uniwersytetu Warszawskiego, 2006.

Modzelewski, Karol. Barbarzyńska Europa. Warszawa: Iskry, 2004.

Pálfalvi, Lajos. „Jerzy Stempowski w piekle Słowian”. Slavistika. Areálová slavistika. Stredoeurópske štúdiá. Zborník materiálov z medzinárodného vedeckého seminára, konaného 3. októbra na FFPU v Prešove. Ed. M. Mitka. Prešov: Filozofická Fakulta Prešovskej Univerzity v Prešove, 2015. S. 237-247.

Pálfalvi, Lajos. „O nieeuropejskich korzeniach Węgrów. Nienaukowe teorie Ference Badinyego Jósa”. Nowoczesność i sarmatyzm. Red. P. Czapliński. Poznań: Wydawnictwo „Poznańskie Studia Polonistyczne", 2011. S. 109-118. 
Stempowski, Jerzy. W dolinie Dniestru. Listy o Ukrainie. Wybrał, oprac. i posłowiem opatrzył A.S. Kowalczyk. Warszawa: LNB, 1993.

Stempowski, Jerzy. Esszék Kasszandrának. Przeł. Csaba Galambos et al. Budapest: Orpheusz Kiadó, 1999. Stempowski, Jerzy. Od Berdyczowa do Lafitów. Wybrał, oprac. i przedmową opatrzył A.S. Kowalczyk. Wołowiec: Czarne, 2001. 
